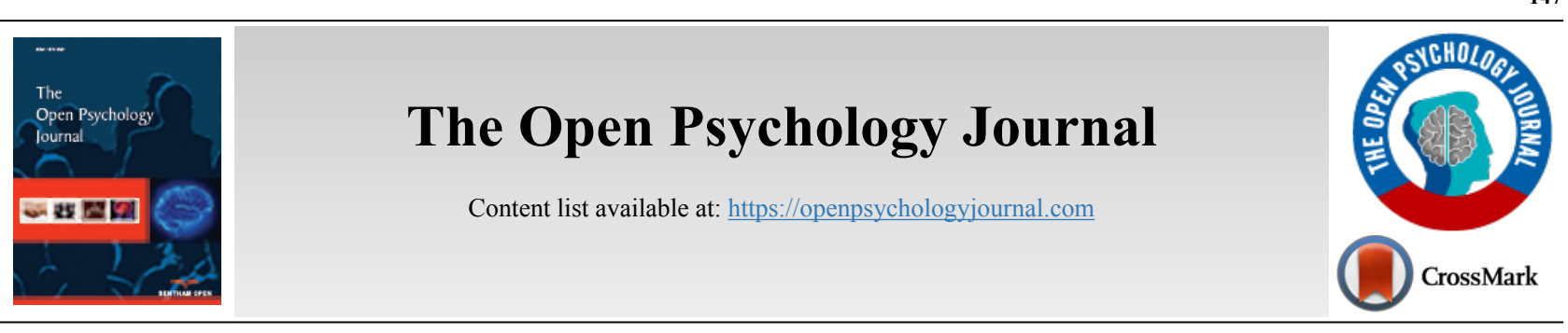

RESEARCH ARTICLE

\title{
Evaluation of the PELITA Bullying Prevention Program: A Study of Elementary School Teachers in Kudus, Indonesia
}

\author{
Latifah Nur Ahyani ${ }^{1, *}$, Ridwan Budi Pramono ${ }^{1}$, Rr Dwi Astuti ${ }^{1}$, Fajar Kawuryan ${ }^{1}$ and Jayanti Putri Purwaningrum ${ }^{2}$ \\ ${ }^{1}$ Department of Psychology, University of Muria Kudus, Jln. Gondangmanis, Bae, Indonesia \\ ${ }^{2}$ Mathematics Education Department, University of Muria Kudus, Jln. Gondangmanis, Bae, Indonesia
}

\begin{abstract}
:
Background:

Bullying has become a severe problem in the educational context. Along with many other countries, Indonesia is also concerned about bullying problems. PELITA (Bullying-Free Psychoeducation for Indonesia) is a pilot program that is expected to become a foundation for a program in bullying prevention, targeted especially to prevent bullying by teachers in Kudus.
\end{abstract}

Objective:

This study aimed to analyze the changes in empathy scores, emotional regulation, and efficacy of teaching before and after undergoing the program.

Methods:

The researcher then conducted qualitative analysis to determine the narrative results related to subjects' understanding of bullying and empathy, subjects' ability to regulate emotions, and the teachers' efficacy in teaching. This study used a quasi-experimental one-group pre-test post-test design with a convergent mixed methods approach. Using a mixed methods approach, we were able to compare and integrate findings from the quantitative and qualitative data. Participants were elementary school teachers selected to represent various areas in the Kudus district. Data collection was conducted using a scale, interviews, and focus group discussions.

Results:

The results showed that, from the three variables, empathy and emotion regulation did not see a significant increase. However, the variable of teacher efficacy showed a significant improvement.

\section{Conclusion:}

The qualitative and quantitative data obtained in this study evidently complements each other. Several improvements in this programs that needs attention, are knowledge transfer about learning disability, mastery of techniques related to rewards and punishment, as well as shaping techniques and other behavioral modification techniques. The analysis, conclusion, and implication will be discussed further in this article.

Keywords: Bullying, Empathy, Emotion regulation, Teaching efficacy, PELITA, Variables.

\begin{tabular}{|l|l|l|r}
\hline Article History & Received: May 20, 2019 & Revised: July 8, 2019 & Accepted: July 16, 2019
\end{tabular}

\section{INTRODUCTION}

Bullying is any type of repeated aggression, both verbal or physical, towards one or more people to disturb a victim [1]. Bullying can appear in many forms, but generally can be classified into two: direct and indirect. Bullying/confrontation done directly is more open, such as physical or verbal aggres-

\footnotetext{
* Address correspondence to this author at the Department of Psychology, University of Muria Kudus, Jln. Gondangmanis, Bae, Indonesia;

Tel: (+62291)438229; E-mail: latifah.nur@umk.ac.id
}

sion (e.g.., teasing, mocking, threatening, or hitting). Indirect bullying tends to take the form of manipulative social behavior, carried out repeatedly and aggressively in a more covert manner such as spreading rumors, gossip and in specific exclusion from groups [1 - 3].

Bullying is one of the most common problems in the majority of countries around the world - both in rural and urban cities, in every social strata, in schools and educational environments, in romantic relationships between lovers, or 
even at work [1]. In Indonesia, the Indonesian Child Protection Commission (KPAI) states that children who are victims of bullying, terrorism, cyberbullying, and pornography are still a large concern [4]. This is reinforced by statistics from the Ministry of Social Affairs that found an increase of bullying cases in 2016, where among 3580 incidents, 14 percent were bullying [5].

School is an environment that is prone to bullying. School bullying is prevalent throughout the world although the severity varies in each country, from $5 \%$ to $30 \%$ in developed countries [6] to $10 \%-60 \%$ in economically developing countries [7]. School bullying does not only occur among fellow students but also by teachers to students, $35.7 \%$ of students experienced violence from teachers or employees [8]. School bullying is sometimes caused by teachers who bully their students or ignore bullying behavior that they observed. An ethnographic research entitled Dude You're a Fag: Masculinity and Sexuality in High School by C.J. Pascoe found that education personnel often ignore cases where students become victims of bullying by teachers, teachers ignore bullying behavior or students' reports of bullying behavior [9].

News coverage in Indonesian mass media regarding cases of violence that involve teachers as suspected perpetrators have lately increased. Teachers often commit physical violence to students for not doing their homework or coming late to class [10 - 13]. Our preliminary study found several conclusions. Our findings found that workload regarding the curriculum and target learning outcomes was felt to be very excessive, with parents having an uncooperative attitude and perceiving that education is entirely the responsibility of teachers and schools. In other words, parents assume that how good and bad their children depends on the influence of teachers and schools. This causes the emergence of teacher permissiveness, in which the teacher only focuses on teaching or transferring knowledge; not on educating students. The behavior modification method used by teachers has mostly taken the form of punishment which teachers consider fast and effective, despite it often not serving any educational purposes.

The number of violence and bullying incidents involving teachers certainly raises its concerns. Ideally, school is a safe place, meaning that every student has the right to feel safe at school. However, bullying gradually reduces that sense of security. Teachers and education personnel are responsible for the safety of students in schools, and they are obliged to guarantee this [14]. Bullying cases involving teachers are crucial issues that must be resolved immediately as children spend the second largest proportion of their time, right after home, at school; thus it is very logical to see schools as part of bullying problems but also as solutions for bullying [15].

Elementary education is the period in which the psychosocial development stage begins, a period that shapes children's social and emotional development [16]. Elementary education is a crucial period where children tend to emulate behaviors that arise in their environment. This is because children still have to learn to express emotions and what they feel right. Children may act aggressively if they feel depressed and are unable to express their feelings and desires, by threatening and humiliating a person, getting involved in direct verbal language and physical aggression, or indirect behavior such as gossiping and isolating friends from groups [2]. The teacher is one of the most appropriate models for students. Modeling behavior that promotes mutual respect and safety of both teachers and students will shape a relationship of mutual respect that is distant from bullying behavior [9]. Individuals who experience bullying or witness bullying do not necessarily become bullying perpetrators, but research shows that witnessing and/or experiencing aggressive behavior, particularly various forms of aggressive behavior, greatly affect the probability of individuals performing violence in the future [1].

\subsection{PELITA Intervention Program}

PELITA is a program developed and implemented as an effort to answer bullying problems. PELITA is an acronym for Bullying-free Psychoeducation for Indonesia.This program aimed to reduce teacher bullying behavior by providing basic knowledge about bullying, increasing empathy, helping teachers to regulate their emotions and encouraging teachers to practice bullying-free behavior in teaching and learning activities so that they can be an example for their students. Fostering empathy and basic social-emotional skills is essential and should be done since childhood [17]. A positive relationship between teachers and students can be built in various ways: through verbal language (e.g., tone of voice, language usage) and non-verbal language (e.g., gesture, eye contact), constructive handling, as well as sharing emotional social experiences which is also deemed very important [18]. This cannot positive relationship cannot be built if the teachers bully students, both consciously or unconsciously. Empathy is an important element in an effort to reduce violence and bullying behavior, where increasing empathy can prevent the emergence of such behaviors [19].

Effective emotional regulation includes the ability to manage emotions flexibly in accordance with the demands of the environment as well as the ability of individuals to regulate emotions and be able to interpret events that they experienced, in order to create an adaptive mindset and behavior [20]. Teachers who are less able to understand students and occasionally find matters that do not fulfill their expectations are prone to anxiety and may lead to distortion of thought and misunderstandings related to these events that, in turn, gives rise to maladaptive responses. The thing that must be done by an individual when experiencing an inconvenient event is to accept the event as a reality that must be faced [21]. The next step is to change the emotions that arise as a result of the event because shifting to positive emotions will evoke positive beliefs and thoughts that will conjure adaptive behaviors or responses. This indicates the importance of ability for emotional control as a teacher when dealing with certain events. The teacher should have sufficient emotional regulation ability so that he/she are more able to accept and face various events beyond his/her expectations. The emotional regulation process itself includes being able to accept events that occur and respond appropriately and adaptively without being affected by negative emotions [20, 22].

Self-efficacy affects the course of actions, goals, and 
challengesthat a person takes, their commitment to achieving those things, as well as how individuals overcome obstacles and pressures in life [23]. Teachers with a high level of selfefficacy certainly do not behave permissively and embarrassingly in dealing with students' problems. Embarrassment and permissive attitudes that emerge indicate that teachers are increasingly uncertain in educating. Efficacy is the main mediator of behavior and behavior change. Efficacy influences choices and actions that will be carried out by individuals. One tends to choose activities and tasks that they feel confident in carrying out and tend to avoid activities that feel otherwise [14]. It is important for teachers to have high self-efficacy [24]. Teachers with high self-efficacy are more persistent in teaching and tend to work more optimally in helping students achieve their potential $[25,26]$.

\section{METHODS}

\subsection{Procedure}

This study aims to examine the effectiveness of PELITA as a bullying prevention program. Subjects in this study were elementary school teachers in Kudus Regency, Central Java, Indonesia. The research subjects were 58 teachers who were determined based on purposive sampling, where the subject was selected based on certain characteristics determined by the researchers. This data collection was done using a quasiexperimental one-group pretest-posttest design [27], while data analysis used a convergent mixed methods approach. This method is done by collecting qualitative and quantitative data within approximately the same time frame, analyzed separately, then integrated during interpretation to determine the possible source of convergence or divergence [28]. A mixed methods design is useful when stand-alone quantitative or qualitative approaches are not sufficient to explain research problems [29]. The data collected by researchers consisted of variables of empathy, emotion regulation, and teachers' teaching efficacy. Qualitative data was collected using interviews, and Focus Group Discussions (FGD). The research was carried out for four months. The teachers were asked to fill the empathy scale, emotional regulation, and teaching efficacy at the beginning and end of the training. Teachers also undergo interviews and group discussions conducted prior, during training, and after training.

All teachers underwent three hours of training, once a week for three months. During the training, the teachers were given an overview of the training as well as materials related to bullying, empathy, emotion regulation technique and were also asked to demonstrate teaching without bullying. The teacher also gets handbooks and training materials. Teachers are provided with worksheets, which contained tasks that must be completed by the teacher during their teaching process in the school environment.

\subsection{Measures of Variables}

An adapted scale was used for the purpose of this study. Teachers completed 29 items from the Empathy Quotient Scale [30] that had an alpha Cronbach of .860. For the emotion regulation variable, teachers completed 26 items from the Difficulties in Emotion Regulation Scale [31] that had an alpha
Cronbach score of 0.864 . The efficacy scale completed by the teachers is an 11-item scale from The Teaching Efficacy Scale [32] that had an alpha Cronbach of 0.942.

Interviews and FGDs were conducted to find out the teacher's knowledge regarding bullying, the teacher's experience of bullying during teaching, the teacher's experience related to the tasks given during training and what the teacher experienced and felt when implementing training materials during the learning process.

\section{RESULTS}

\subsection{Quantitative Analysis}

Interventions through the PELITA program effectively increases the variable of teacher's efficacy to the medium category. Whereas, the variables of empathy and emotion regulation did not experience a significant increase. The teaching efficacy variable shows an effect size of 1.31 , which is considered a strong effect [33].

Table 1 shows the means and standard deviation of the three variables. The standard deviation shows the amount of variation in the data, which means that the subjects who experienced an increase in scores also vary.

\subsection{Qualitative Analysis}

The qualitative data illustrates the dynamics related to teachers' understanding of bullying and their levels of empathy, emotion regulation, and teaching efficacy. The researcher did not conduct quantitative analysis regarding teachers' knowledge about bullying, however, considering that the core of this program was related to bullying. Hence teachers' knowledge and understanding of bullying should then be explored deeper in the qualitative analysis.

\section{DISCUSSION}

This study aimed to evaluate the PELITA program using quantitative and qualitative analysis. Quantitative analysis in Tables $\mathbf{1}$ and $\mathbf{2}$ shows that there are no significant differences between empathy and emotion regulation before and after training. The results differed in the teaching efficacy variable, which showed differences before and after training. When the result is not statistically significant, we cannot assume that there is no effect. The difference might not be statistically different, but this might be caused by the small sample size. Statistical significance can indeed be calculated and can, therefore, be shown objectively, but from a practical point of view, it needs to be based on reasoning because the significance or absence of statistical test results depends, among others, on the sample size and data variability [34, 35].

\subsection{Empathy}

Education, especially formal education, is a continuous process. Teachers, especially elementary school teachers, have many roles in the education process. The ideal teacher must pay attention to the development of children's cognitive, affective, and psychomotor abilities. Empathy is the ability to observe and understand the development of a child's abilities. Empathy is an inseparable part of teaching competence, in 
addition to pedagogical competence, the competence of knowledge mastery, and communication competency [36]. Empathy is the ability to adopt other people's perspectives but simultaneously maintain awareness that there are differences between other people's perspectives with their own perspectives [37].

Table 1. Means and standard deviation for variables pretest and posttest

\begin{tabular}{|c|c|c|c|}
\hline \multicolumn{2}{|c|}{} & $\boldsymbol{M}$ & $\boldsymbol{S D}$ \\
\hline \multirow{3}{*}{ Pre } & Empathy & 142.18 & 9.98 \\
\cline { 2 - 4 } & Emotion Regulation & 70.51 & 9.12 \\
\cline { 2 - 4 } & Teaching Efficacy & 37.39 & 9.24 \\
\hline \multirow{3}{*}{ Post } & Empathy & 143.09 & 10.5 \\
\cline { 2 - 4 } & Emotion Regulation & 70.81 & 10.81 \\
\cline { 2 - 4 } & Teaching Efficacy & 46.86 & 4.29 \\
\hline
\end{tabular}

Table 2. Description of $\mathrm{N}$-gain and significance test on the three variables

\begin{tabular}{|c|c|c|}
\hline Variables & Mean of N-gain Score & sig (2-tailed) \\
\hline Empathy & 0.00 (low) & 0.423 \\
\hline Emotion regulation & 0.01 (low) & 0.951 \\
\hline Teaching Efficacy & 0.4 (medium) & 0.000 \\
\hline
\end{tabular}

Research on the role of teachers' empathy in dealing with bullying [38] found that teachers' empathy is an important factor in creating and managing a positive school climate, which leads to prevention of bullying.

In this research, the insignificant results regarding the increase of empathy score can be seen in Table 2, which illustrates the distribution of the subject categories Table 3) with 56 subjects in the low category and 2 subjects in the medium category. The qualitative data (Table 4) also strengthens the results of quantitative analysis. After undergoing training, teachers who generalized student performance began to show the desire to understand the condition of students who experience learning difficulties and behavioral problems. This desire is not accompanied by the teachers' knowledge about students' learning disabilities and deviant behaviors, leading teachers to often become confused on how to behave.

Table 3. Categorization of $\mathrm{N}$-gain score based on subjects

\begin{tabular}{|c|c|c|c|}
\hline $\begin{array}{c}\text { Categorization of N-gain } \\
\text { Score }\end{array}$ & Empathy & $\begin{array}{c}\text { Emotion } \\
\text { Regulation }\end{array}$ & $\begin{array}{c}\text { Teaching } \\
\text { Efficacy }\end{array}$ \\
\hline Low (N-Gain $\geq 0.7)$ & 56 & 58 & 15 \\
\hline $\begin{array}{c}\text { Medium (0.7 > N-Gain } \geq \\
0.3)\end{array}$ & 2 & - & 27 \\
\hline High (0.3 > N-Gain) & - & - & 16 \\
\hline
\end{tabular}

Table 3 illustrates the number of subjects in each $\mathrm{N}$-gain score category for each of the three variables. In the N-Gain test, researchers used the categorization mean of $\mathrm{N}$-gain score, which refers to Hake's categorization [34].It can be seen that in the score of empathy and emotion regulation still predominantly remains in the low category, which is a contrast to teaching efficacy, where the distribution of subject categories is more varied and mostly in the medium category.

In several subjects, researchers obtained data which states that, in reality, teachers knows the causes of students' low academic performance, but because the demands of the school to achieve the minimum passing grade, teachers ignores these causes. Teachers tend to raise the grade of students at the end of the semester rather than finding out more about why student have academic difficulties. This is an irony, because teachers are more focused on completing the work load determined by the ministry of basic education, which refers to the fulfillment of credit scores Simply put, the fulfillment of teaching hours is more focused on quantity, not on the quality of learning. Teachers strive to fulfill teaching hours which are part of their obligations, which leads them to occasionally ignores many other things, like trying to understand students well enough in order to help them reach optimal achievements.

\subsection{Emotional Regulation}

The strategy used to teach teachers in this program is the relaxation technique and the release of emotion when experiencing unpleasant stimuli. Children who do not want to do their tasks may trigger the teachers' anger but also can cause sadness. Teachers who can effectively regulate their emotions are expected to express emotions appropriately. Research on emotional regulation by teachers [20] found that teachers with emotion regulation skills tend to focus on how to regulate their emotions and the emotions of their students, as well as attempting to reduce negative emotions. Other studies related to emotional regulation in teachers [39] show that the use of emotional regulation strategies has a positive effect on teachers' deep acting. Deep acting is the ability to find the positive side of events that are initially seen as negative, where this process requires individual cognitive abilities and positive emotions.

Quantitative analysis in Table 2 shows that increasing emotional regulation scores is not significant. In Table 4, it is confirmed that the distribution of subject categories is predominantly at the low level. This is in accordance with the qualitative description in Table 4. Despite the subjects beginning to learn to apply emotion regulation techniques as well as learning to separate personal problems from their role as a teacher at school, teachers' have not been able to implement these teachings properly. The teaching activity is often the main reason. Another reason is that teachers' applying emotion regulation techniques in public environments is not yet considered normal. Even though they feel the benefits of the techniques obtained, they have not been able to encourage them to routinely apply the techniques they learned.

\subsection{Teaching Efficacy}

A relationship between the efficacy of teachers and educational outcomes has been proven by past research, where perseverance, enthusiasm, commitment, and teachers' behaviors affect students' achievement [40]. Teachers who have high efficacy believe in their capacity and capability to solve problems within the educational context. In this study, teachers with high efficacy were expected to be able to become role models of anti-bullying through the learning process 
carried out in schools. In the context of education, the term efficacy is often highly associated with the term teaching efficacy which is defined as the teacher's belief that they can influence students, even if the student has difficulty or has no motivation [41]. The level of teaching efficacy can also be used to predict the quality of the relationship between teachers and students, as well as the quality of the classroom environment they create, both of which can affect students [42].

The interview results regarding the efficacy variable strengthen the results of statistical analysis in Table 2. Initially, the teachers' understanding of violence against students was limited to physical violence. The educational methods that the teacher experienced as a child also formed the perspective that physical punishment is an effective punishment in educating students. The emergence of cases of physical violence, which led to legal consequences confused that teachers could not educate students as they usually do, due to limited knowledge on how to educate and shape student behavior. Teachers feel worried that applying sanctions or punishment to students will lead to problems with parents. The training program attended by the teacher opens a new perspective on classroom management and student handling. They are given knowledge the of how to condition classes and study various cases of learning disability that is often experienced by students. This increased the teachers' insight into how to deal with and handle

\section{Table 4. Qualitative analysis of each variable}

\begin{tabular}{|c|c|c|c|c|}
\hline & Bullying & Empathy & Emotion Regulation & Teaching Efficacy \\
\hline $\begin{array}{l}\text { Initial } \\
\text { Interview }\end{array}$ & $\begin{array}{l}\text { There is a presumption } \\
\text { that educating students } \\
\text { using verbal and physical } \\
\text { aggression is normal. } \\
\text { This aggression occurs in } \\
\text { order to drive students to } \\
\text { behave better. } \\
\text { Teachers perceive that } \\
\text { the only way to shape a } \\
\text { student's behavior is } \\
\text { through harsh verbal } \\
\text { warnings and physical } \\
\text { aggressiveness. }\end{array}$ & $\begin{array}{l}\text { Teachers do not fully } \\
\text { understand the psychological } \\
\text { conditions and cognitive } \\
\text { abilities of students, which } \\
\text { leads the teachers to } \\
\text { generalize students' } \\
\text { conditions. } \\
\text { This elicits the same } \\
\text { responses from teacher to all } \\
\text { students regardless of the } \\
\text { root of the problem. } \\
\text { This attitude causes teachers } \\
\text { to become emotional when } \\
\text { facing students who are not } \\
\text { ableto master the taught } \\
\text { subjects. This condition leads } \\
\text { to discriminative behavior } \\
\text { that leads to bullying. }\end{array}$ & $\begin{array}{l}\text { Teachers often feel discomfort, anger, and } \\
\text { confusion when students have difficulty } \\
\text { understanding the subjects being taught. } \\
\text { These feelings emerge largely due to the } \\
\text { teachers' concerns about students not } \\
\text { achieving the learning objectives of the } \\
\text { subject, with a particular concern } \\
\text { regarding students being below the } \\
\text { passing gradedetermined by the school. } \\
\text { Teachers recognize that personal and } \\
\text { household conditions of the teacher affect } \\
\text { their emotional state at school. This } \\
\text { awareness has not been followed by the } \\
\text { ability to isolate the problems that occur at } \\
\text { home and those that occur at school, } \\
\text { which leads to teachers' emotional } \\
\text { reactions at school when an unpleasant } \\
\text { event causedby the students occurs. } \\
\text { Emotional reactions shown by teachers in } \\
\text { schools are often overreacted and } \\
\text { disproportionate. }\end{array}$ & $\begin{array}{l}\text { Teachers avoid violence because it } \\
\text { has become a school rule. On the } \\
\text { other hand, they experience } \\
\text { confusion due to their } \\
\text { understanding that physical and } \\
\text { verbal aggressiveness is natural and } \\
\text { effectivein their efforts to educate } \\
\text { students. } \\
\text { Teachers tend to be permissive to } \\
\text { the behavior of students who break } \\
\text { the rules, because they are afraid to } \\
\text { take action that will eventually lead } \\
\text { them to deal with law enforcement. } \\
\text { Teachers tend to display verbal } \\
\text { aggressivity, both consciously or } \\
\text { unconsciously. Examples of verbal } \\
\text { aggressivity carried out by teachers } \\
\text { are: making fun of students who } \\
\text { cannot complete a problem in front } \\
\text { of the whole class; emotional } \\
\text { yelling to calm a loud classroom. }\end{array}$ \\
\hline $\begin{array}{l}\text { Interview } \\
\text { after } \\
\text { training }\end{array}$ & $\begin{array}{l}\text { Teachers understand the } \\
\text { forms of bullying and } \\
\text { how iteffects students } \\
\text { Teacher realize that the } \\
\text { bullying behavior } \\
\text { displayed by a teacher is } \\
\text { an example for students } \\
\text { to do the same to their } \\
\text { friends }\end{array}$ & $\begin{array}{l}\text { Teachers understand the } \\
\text { importance of knowing the } \\
\text { background of students who } \\
\text { have cognitive and } \\
\text { behavioral problems. By } \\
\text { understanding the condition } \\
\text { of students, teachers can be } \\
\text { more sensible in their attitude } \\
\text { and behavior. } \\
\text { Some teachers have begun } \\
\text { theattempt to understand the } \\
\text { conditions of their students, } \\
\text { but because of their limited } \\
\text { knowledge of students' } \\
\text { learning difficulties, teachers } \\
\text { were often confused in } \\
\text { determining their attitude } \\
\text { towards the problem. } \\
\text { In some cases, the main } \\
\text { targets of learning that must } \\
\text { be achieved tend to force } \\
\text { teachers to ignore the need to } \\
\text { understand students' } \\
\text { conditions. } \\
\text { The assumption that parents } \\
\text { have a greater role in } \\
\text { overcoming their children's } \\
\text { problems also contributes to } \\
\text { this neglect. }\end{array}$ & $\begin{array}{l}\text { Teachersexperience the positive impact of } \\
\text { the emotion regulation technique taught } \\
\text { during training. Teachers begin to learn to } \\
\text { separate personal problems from their role } \\
\text { as a teacher. } \\
\text { But despite feeling the positive impact of } \\
\text { the techniques learnedduring training, it } \\
\text { seems that the routine implementation in } \\
\text { everyday life is still rarely done. } \\
\text { The reason to why implementation has yet } \\
\text { to be carried out routinely is the number of } \\
\text { activities teachers are involved in, hence } \\
\text { they sometimes forget to apply the } \\
\text { techniques. Some teachers revealed that } \\
\text { they felt embarrassed to use the technique } \\
\text { in the public environment. }\end{array}$ & $\begin{array}{l}\text { Teachersbecome aware of the } \\
\text { various strategies and techniques } \\
\text { that can be done to shape a desired } \\
\text { behavior from students without } \\
\text { bullying } \\
\text { Teachers considers various } \\
\text { approaches that can be taken in the } \\
\text { process of educating students. One } \\
\text { of them is by giving a positive } \\
\text { response to students who succeed } \\
\text { in working on a problem. } \\
\text { Despite encountering various } \\
\text { obstacles such as time and } \\
\text { resources, there have been few } \\
\text { attempts to consult with someone } \\
\text { who has expertise in student } \\
\text { learning difficulties that allows the } \\
\text { teachers to get an understanding of } \\
\text { the condition of the student. }\end{array}$ \\
\hline
\end{tabular}


their students. This can be shown by teachers providing a positive response to students who can answer questions correctly (Table 4).

In handling children with learning disability and behavioral problems, efforts to consult experts or psychologists sometimes are hindered by obstacles, both in terms of time and other resources (e.g., finance and energy). Subjects stated that they sought to create a positive learning environment within the classroom, despite them still finding it difficult to deal with students who were academically or behaviorally problematic. This result is supported by the research conducted by Vahedi, Azar and Golparvar which states that teachers who learn techniques and strategies to handle bullying have a desire to implement them [43].

\section{CONCLUSION}

The qualitative and quantitative data obtained in this study evidently complements each other. However, there are several matters that were a concern for the researcher. In the empathy variable, it was not that the subjects were unwilling to change, but their limited knowledge of student learning difficulties inhibits the subject from empathizing with students who have learning difficulties and behavioral problems. Their ignorance is much due to their focus on the burden of teaching objectives that must be fulfilled. The subject's emotional regulation ability is limited by embarrassment in applying regulatory techniques in the public environment. Another reason is immersion in delivering teaching materials, leading subjects to forget that they have techniques that can help regulate their emotions. Although teaching efficacy shows positive results compared to the other two variables, its application in teaching and learning activities still faces many limitations.

This pilot program requires some improvements in the future. Several improvements that need to be done, among others, are knowledge transfer about learning disability, mastery of techniques related to rewards and punishment, as well as shaping techniques and other behavioral modification strategies. Intensive assistance especially in the application of emotion regulation techniques should be carefully considered as the assignments and once-a-week face-to-face were not optimal. Teachers also require time to adapt towards the various activities that have been established in the training program.

Another approach that can be done apart from the applying bullying prevention program to teachers is to implement it with education personnel, parents and policy makers. Stakeholders are an important part of handling bullying. The teacher will not optimally play a role in this bullying prevention if both the system and the rules in education in Indonesia do not accommodate this matter.

There are several limitations in this study, with the main limitations being the absence of a comparison group and a small sample size. Without a comparison group, it is difficult to generalize the results [44]. The absence of a comparison group is due to the limited number of teachers who can take part in the training. The limited subject in this study was due to the limited number of teachers who were willing to take part in the program, even though the researchers had collaborated with the local department for basic education in inviting teachers to attend the training. Each elementary school has only one teacher for each class, so if teachers attend a training for a longer period of time, it becomes burdensome for the school because other class teachers must handle two classes at a time. Another limitation is regarding the various variables that has to be analysed, preventing researchers from having a deeper analysis of each variable. Further analysis of each variable is encouraged as opposed to simply measuring the effectiveness of the program.

\section{ETHICS APPROVAL AND CONSENT TO PARTICIPATE}

Not applicable.

\section{HUMAN AND ANIMAL RIGHTS}

No animals/humans were used for studies that are basis of this research.

\section{CONSENT FOR PUBLICATION}

Not applicable.

\section{FUNDING}

The Ministry of Research and Technology of the Republic Indonesia funded the study.

\section{CONFLICT OF INTEREST}

The authors declare no conflict of interest, financial or otherwise.

\section{ACKNOWLEDGEMENTS}

This research was sponsored by the Ministry of Research and Technology of the Republic of Indonesia. This research would have not been possible without financial support from the government. We also express our appreciation to our colleagues, assistant researchers from Muria Kudus University who have worked tirelessly to complete this project. We also thank the Education and Sports Office of Kudus Regency, Indonesia, the teachers who have participated in the program from the beginning to the end: without them, this research would have not been possible.

\section{REFERENCES}

[1] Swearer SM, Collins A, Berry B. Bullying. 2nd ed. Encycl Hum Behav 2012; pp. 417-22.

[2] Juvonen J, Espinoza G, Schacter HL. Bullying Encycl Ment Heal Second Ed. 2015; 1: pp. 216-.

[3] Persson M, Svensson M. The willingness to pay to reduce school bullying. Econ Educ Rev [Internet] 2013; 35: 1-11. [http://dx.doi.org/10.1016/j.econedurev.2013.02.004] 
[4] Rahayu CM. Hari Anak Nasional, KPAI Soroti Kasus Bullying hingga Pornografi [Internet]. 2017 [cited 2018 Oct 4]. Available from:. https://news.detik.com/berita/d-3569939/hari-anak-nasional-kpai-sorot i-kasus-bullying-hingga-pornografi

[5] Setiawan S. ASTAGA, Tujuh Bulan Terakhir Kementerian Sosial Terima 117 Laporan Kasus Bullying - Tribun Jateng [Internet]. 2017 [cited 2018 Oct 4]. Available from:. http://jateng.t ribunnews.com/2017/07/23/as ta ga-tujuh-bu lan-tera khirkementerian -sosial- terima-117-lapo ran-ka sus-bullying

[6] Currie C, Zanotti C, Morgan A, Currie D, de Looze M, Roberts C, et al. Social determinants of health and well-being among young people.Health Behaviour in School-aged Children (HBSC) study: International report from the 2009/2010 survey World Heal Organ Heal Policy Child Adolesc No 6 [Internet] 2012; 6(1): 1-272. Available from: http://www.euro.who.int/en/health-topics/Life-sta ges/ chi ld-and-ado lescent- health /publications/2012/ social-determin antsof-health- and-wel 1-being-among-young-people.- health-beha viourin-school-ag ed- children-h bsc-st udy

[7] Azeredo CM, Levy RB, Araya R, Menezes PR. Individual and contextual factors associated with verbal bullying among Brazilian adolescents. BMC Pediatr[Internet] 2015; 15(1): 49 [http://dx.doi.org/10.1186/s12887-015-0367-y] [PMID: 25925995]

[8] Jevtic B, Petrovic ZS, Stankovic AZ. Victims or Bullies - Students or Teachers. Procedia Soc Behav Sci[Internet] 2014; 141: 587-96.http://link inghub.elsevier.com/retr ieve/pii/S 1877042814 035277

[http://dx.doi.org/10.1016/j.sbspro.2014.05.103]

[9] Lucas AM. Paying attention to ourselves: Modeling anti-bullying behavior for students. Engl J[Internet] 2012; 101(6): 13-5.http://search. ebscohost. com/ login.aspx?direct=true\& $\mathrm{db}=$ eric \& AN=EJ1001151\&lang $=$ es\&site $=$ ehost-live $\% 5$ Cnhttp://www.ncte.org/ journals/ej/ issues/v101-6

[10] Putra P. Terdakwa Guru Cubit Siswa Hanya Dihukum Percobaan [Internet]. 2016 [cited 2018 Oct 4]. Available from: . https:// daerah.sindonews .com /read/1128718/23/ terdakwa-guru-cubit-siswahanya-dihukum-percobaan-1470297057

[11] Panggabean J. Terlambat Masuk Kelas, Siswa SD Ditusuk Guru. 2016 [cited $2018 \quad$ Oct 4 ]. Available from:. https://daerah.sindonews.com/read/1099863/1 91/terlambat-m asukkelas-siswa-sd-ditusuk-guru-1460296688

[12] Bugma. Oknum Guru SD Pukuli Muridnya Hingga Memar. 2016 [cited 2018 Oct 4]. Available from:. https://daerah.sindonews.com/read/11068 68/192/oknum-g uru-sdpukuli-muridnya-hingga-memar-1462672099

[13] Rofik M. Tak Kerjakan PR, Paha Siswa SD Ini Membiru Dipukul... [Internet]. 2017 [cited 2018 Oct 4]. Available from:. https://daerah.sindon ews.com/read/1237277/194/tak-kerjakan-prpaha-s iswa-sd-ini-membiru-dipukul-guru-1504706347

[14] Choi LJ, Syawal M, Adzrieman N. Teachers' self -efficacy in dealing with bullying among secondary schools students in malaysia. J Educ Soc Sci 2016; 4: 48-56.

[15] Howard NM, Horne AM, Jolliff D. Self-efficacy in a new training model for the prevention of bullying in schools. J Emot Abus [Internet] 2001; 2(2-3): 181-91.http://ov idsp.ovid.com/ov idweb.cgi? $\mathrm{T}=\mathrm{JS} \& \mathrm{CSC}=\mathrm{Y} \& \mathrm{NEWS}=\mathrm{N} \& \mathrm{PAGE}=$ fulltext $\& \mathrm{D}=\mathrm{em}$ ed5\& $\mathrm{AN}=2002144506$, http:/ /lshtmsf x.ho sted .exlibri sgro up.com/ lshtm? sid=OV ID: embase \& id= pmid: \& i d=d oi: $10.1300 / \mathrm{J} 13$ $5 \mathrm{v} 02$ n02_11\&i s sn $=1092-6798 \&$ isbn $=\&$ volume $=2 \&$ issue $=2-3 \&$ spa ge $=181 \&$ pages $=181-191$ [http://dx.doi.org/10.1300/J135 v02n02 11]

[16] Demirbağ BC, Çiçek Z, Yiğitbaș Ç, Özkan ÇG, Dinçer A. The relationship between types of bullying experienced by primary school students and their anxiety, State-Trait, Self-Esteem and Certain SocioDemographic characteristics. Procedia Soc Behav Sci 2016; 2017(237): 398-404

[17] Nickerson AB, Aloe AM, Werth JM. The relation of empathy and defending in bullying: A meta-analytic investigation. School Psych Rev[Internet] 2015; 44(4): 372-90.http://n aspjourna ls.org/ doi/1 $0.17105 /$ spr-15-00 35.1

[http://dx.doi.org/10.17105/spr-15-0035.1]

[18] Hymel S, McClure R, Miller M, Shumka E, Trach J. Addressing school bullying: Insights from theories of group processes. J Appl Dev Psychol[Internet] 2015; 37(1): 16-24

[http://dx.doi.org/10.1016/j.appdev.2014.11.008]

[19] Ozcan Y, Çifci EG. The effect of empathy level on peer bullying in schools. Humanity and Social Sciencies Journal 2009; Vol. 4: pp. $31-8$.
[20] Taxer JL, Gross JJ. Emotion regulation in teachers: The "why" and "how.". Teach Teach Educ[Internet] 2018; 74: 180-9.

[http://dx.doi.org/10.1016/j.tate.2018.05.008]

[21] Ellis A. Early theories and practices of rational emotive behavior therapy and how they have been augmented and revised during the last three decades. J Ration - Emotive Cogn -. Behav Ther 1999; 17(2): 69-93.

[22] Chrysikou EG, Thompson WJ. Assessing cognitive and affective empathy through the interpersonal reactivity index: An argument against a two-factor model. Assessment [Internet] 2016; 23(6): 769-77.http://journals.sagepub.com/doi/10.1177/1073191115599055 [http://dx.doi.org/10.1177/1073191115599055] [PMID: 26253573]

[23] Bandura A. Guide for constructing self-efficacy scalesSelf-efficacy beliefs Adolesc. 2006; pp. 307-7.

[24] Zulkosky K. Self-efficacy: A concept analysis. Nurs Forum [Internet] 2009; 44(2): 93-102.http://doi.wiley. c om/10. 111 1/j.17 44 -6198.2 0 $09.00132 . x$

[http://dx.doi.org/10.1111/j.1744-6198.2009.00132.x]

[25] Pendergast D, Garvis S, Keogh J. Pre-Service Student-Teacher SelfEfficacy Beliefs: An Insight Into the Making of Teachers. Aust J Teach Educ 2011; 36(12): 46-58.

[http://dx.doi.org/10.14221/ajte.2011v36n12.6]

[26] Takunyaci M, Takunyaci M. Preschool teachers' mathematics teaching efficacy belief. Procedia Soc Behav Sci 2014; 152: 673-8.http://linkinghub.elsevier.com/retrieve/pii/S1877042814053282 [http://dx.doi.org/10.1016/j.sbspro.2014.09.261]

[27] Shadish WR, Cook TD, Campbell DT. Experimental and quasiExperimental for generalized designs causal inference. Handb Ind Organ Psychol 2002; 223: 504.

[28] McCrudden MT, Marchand G, Schutz P. Mixed methods in educational psychology inquiry. Contemp Educ Psychol 2019; 57: 1-8. [http://dx.doi.org/10.1016/j.cedpsych.2019.01.008]

[29] Cresswell JW. Research Design Qualitative, Quantitative, and Mixed Methods Approaches. 4th ed. SAGE Publications Ltd. 2014.

[30] Baron-Cohen S, Wheelwright S. The empathy quotient: an investigation of adults with Asperger syndrome or high functioning autism, and normal sex differences J autism Dev [Internet] 2004; 34(2) Available from: http://1 ink.spr inger.c om /ar ticle/ 10.1023/ B:JADD. 0000022607.19833 .00

[31] Gratz KL, Roemer L. Multidimensional assessment of emotion regulation and dysregulation: Development, factor structure and initial validation of the difficulties in emotion regulation scale. J Psychopathol Behav Assess 2004; 26(1): 41-54.

[http://dx.doi.org/10.1023/B:JOBA.0000007455.08539.94]

[32] Hadjam MNR, Widhiarso W. Efikasi mengajar sebagai mediator peranan faktor kepribadian terhadap performasi mengajar guru. Humanitas (Monterey NL) 2011; 8(1): 1-16.

[33] Cohen L, Manion L, Morrison K. Research Methods in Education. 2007.

[http://dx.doi.org/10.4324/9780203029053]

[34] Hake R. Analizing Change/Gain Scores. Indiana University 1999.

[35] Azwar S. Signifikan Atau Sangat Signifikan? Bul Psikol UGM 2005; 13(1): 38-44

[36] Stojiljković S, Djigić G, Zlatković B. Empathy and Teachers' Roles Procedia - Soc Behav Sci 2012; 69(Iceepsy): 960-6. Available from: http://linkingh ub.els evie r.com/re trieve/pii/S1 87704 281205481X

[37] Carré A, Stefaniak N, D'Ambrosio F, Bensalah L, Besche-Richard C The Basic Empathy Scale in adults (BES-A): Factor structure of a revised form. Psychol Assess 2013; 25(3): 679-91. [http://dx.doi.org/10.1037/a0032297] [PMID: 23815121]

[38] Murphy HR, Tubritt J, O'Higgins Norman J. The role of empathy in preparing teachers to tackle bullying. J New Approaches Educ Res 2018; 7(1): 17-23.

[http://dx.doi.org/10.7821/naer.2018.1.261]

[39] Lavy S, Eshet R. Spiral effects of teachers' emotions and emotion regulation strategies: Evidence from a daily diary study. Teach Teach Educ[Internet] 2018; 73: 151-61.

[http://dx.doi.org/10.1016/j.tate.2018.04.001]

[40] Tschannen-moran M, Woolfolk A. Teacher efficacy: Capturing an elusive construct. Teach Teach Educ 2001; 17: 783-805. [http://dx.doi.org/10.1016/S0742-051X(01)00036-1]

[41] Guskey TR, Passaro PD. Teacher Efficacy: A Study of Construct Dimensions. Am Educ Res J 1994; 31(3): 627-43.http://aer.sagepu b.com/ cgi /doi/ 10.3102/00028312031003627 [http://dx.doi.org/10.3102/00028312031003627]

[42] Miller AD, Ramirez EM, Murdock TB. The influence of teachers' self-efficacy on perceptions: Perceived teacher competence and 
respect and student effort and achievement. Teach Educ 2017; 64: 260-9.

[http://dx.doi.org/10.1016/j.tate.2017.02.008]

[43] Vahedi S, Fathi Azar E, Golparvar F. The effectiveness of school-wide anti bullying programs on teachers' efficacy in dealing with students' bullying behavior. J Fundam Ment Heal 2016; 18(2): 68-75.

[44] Fruth JD, Huber MJ. Teaching prevention: The impact of a universal preventive intervention on teacher candidates. J Educ Hum Dev 2015; 4(1): 245-54.

[http://dx.doi.org/10.15640/jehd.v4n1a22]

\section{(C) 2019 Ahyaniet al.}

This is an open access article distributed under the terms of the Creative Commons Attribution 4.0 International Public License (CC-BY 4.0), a copy of which is available at: https://creativecommons.org/licenses/by/4.0/legalcode. This license permits unrestricted use, distribution, and reproduction in any medium, provided the original author and source are credited. 